\title{
Die beeld van die kerk na buite - enkele Bybelse perspektiewe
}

\author{
B.J. de Klerk \\ Skool vir Kerkwetenskappe \\ Potchefstroomse Universiteit vir $\mathrm{CHO}$ \\ POTCHEFSTROOM
}

E-pos: kwsbjdk@puknet.puk.ac.za

\begin{abstract}
The external image of the church - $a$ few biblical perspectives

What does the Bible teach about the image of the church and does it provide certain guidelines on how the church should promote itself? What does God do with perceptions about His church and what does He expect of the church in this regard? The church has a certain identity as the image/representative of God and has to emanate the image of the Trinity. This identity gives the church the responsibility to administer perceptions about God, the church itself and its environment. To transmit the character, values and convictions of the church, the church should be involved constructively in the world. The church should mainly project the image of the Bridegroom, but in the process should also reflect its own image as being the bride. God administers the perceptions about Himself and His people, but in this regard also gives responsibilities to the church. The church should administer perceptions about God and His people by performing good deeds and by reflecting the idea of hope. The church, as the bride, can only do this if she has a passion for God and her Bridegroom, Christ, but also a burning passion for the church itself.
\end{abstract}

\section{Inleiding}

Is die volgende stelling waar: You can tell the ideals of a nation by its advertisements? (Natal Witness, Today's Reflection: 11, 22 Mei 2000). Kan dit ook van die kerk gesê word dat sy ideale, sy visie, sy hoop afgelei kan word uit die mate en wyse waarop hy sy waardes "adverteer", "reklameer", aan sy geloofsgenote en aan ander oordra? Mag die kerk adverteer en indien wel, hoe moet die kerk dit doen? In antwoord op bogenoemde stelling in die Natal Witness verklaar 'n briefskrywer onom- 
wonde: "Christians are meant to advertise" (McGrath, 2000:21). Hy stel dat kerke moet "adverteer" as hulle hulle invloed wil laat geld:

Have the churches no news for us? According to their own deep conviction they have good news for all mankind. Well then, why do they not go out into the highways and advertise their news? (McGrath, 2000:21).

Hoe behoort die Christen sy goeie nuus oor te dra? Moet die goeie trou van die Comrades-hardloper aanvaar word wat die volle afstand gehardloop het met 'n banier met die naam van sy kerk en die volledige teks van Johannes 3:16 daarop? En indien dan nie op so manier nie: Mag kerke enigsins reklame maak? Mag hulle net oor die Bruidegom praat of ook oor sy bruid? Die persepsie bestaan dat enkele gemeentes en sommige meerdere vergaderings hulle net met verskynsels besig hou wat eintlik niks aan brandende kwessies soos armoede, Vigs en die bestuur van die Afrika-renaissance doen nie. Hoe moet kerke op hierdie persepsies reageer? Hoe moet die persepsies gesien, bestuur en verander word?

Die artikel is 'n soeke na die lig wat die Bybel gee om reklame in/en die kerk te kan beoordeel.

- Wat leer die Bybel oor die identiteit wat die gelowige moet uitstraal, of anders gesê: Wat leer die Bybel oor die reklamepotensiaal van die kerk?

- Is daar sekere riglyne aan die kerk oor hoe sy haarself en haar oortuigings en waardes moet oordra?

- Wat maak God met persepsies oor sy kerk en wat verwag Hy van ons in hierdie verband? Hoe moet ons persepsies bestuur?

Hierdie omvattende onderwerp sal by wyse van enkele snitte uit sekere dele van die Skrif hanteer word om tot veralgemenings te probeer kom.

\section{Die identiteit wat die kerk moet uitstraal}

Wie na die identiteit van die mens in die algemeen en in die besonder die kerkmens vra, moet begin by die skepping van die mens. Het God die mens geskape om enigsins iets uit te straal, iets aan die skepping en ander mense oor te dra? Die leser van Genesis 1 word in verse 26-28 vir iets groots voorberei deur die unieke stelling van God: "Laat Ons mense maak na ons beeld, na ons gelykenis en laat hulle heers ..." (vgl. Hamilton, 1991:134). By die klimaks van sy skeppingswerk gaan God met Homself in konsultasie (Spykman, 1992:223). Die "ons" is 'n aanduiding dat die mens, wat God nou gaan skep, in 'n besondere 
verhouding tot Hom sal staan (vgl. Lenchak, 1996:167; Greenhalgh, 1992:14).

\subsection{Geskep na die beeld, verteenwoordiger van God (Gen. 1:26-28)}

Die grootsheid van die skepping van die mens kom veral tot uitdrukking in die begrippe "beeld" (sêlêm) en "gelykenis/verteenwoordiger" (demoet) (Hamilton, 1991:134). Sêlêm (beeld) beteken "standbeeld" met die oordragtelike betekenis "afbeelding". Demoet benoem in die Ou Testament die hele veld van vergelyking: vanaf werklike afbeeldings tot vae ooreenkomste. Die mens is nie bloot beeld van God nie, maar "gelykenis-beeld" van God. Demoet is versterkend of verrykend by sêlêm te verstaan (Verhoef, 2000:17). So is die mens die unieke voorreg en verantwoordelikheid gegee om 'n geloofwaardige verteenwoordiger van God op aarde te wees, maar nie as plaasvervanger van God nie. Die mens is geskape sodat hy/sy God in sy/haar gesindheid en optrede kan reflekteer (Van Wyk, 1992:9). In die reflektering van God is die mens in sy wese toegerus om, in moderne taal gestel, vir sy Skepper reklame te maak.

Deur die mens as beeld van God te skep, stel die Skepper die mens wesenlik in verhouding tot Hom (Louw, 1999:182). Met die begrip "beeld van God" word die unieke Vader-kind-verhouding aangedui, want die beeld is vergestalt deur kindskap (Mathews, 1996:164). Die mens is uniek in die sin dat hy/sy anders as God is en ook anders as ander skepsels is. Die ander skepsels word elkeen na hulle aard geskep, in teenstelling met die mens wat na die beeld van God gemaak is (Spykman, 1992:226). Die andersheid van die mens teenoor ander geskape dinge is die vertikale gerigtheid van die mens. Omdat God die mens in hierdie verhouding tot Hom plaas, is die mens nie bloot beelddraer van God nie, maar is hy/sy in sy/haar totale menswees beeld van God (Hamilton, 1991:137; vgl. Van Leeuwen, 1997:644).

Die mens is as beeld van God, sy verteenwoordiger, ook by die skeppingswerk van God betrokke. Hy moet God se heerskappy deurvoer, ook in die maatskaplike lewe (Van Rooy, 1996:436), want die mens is aangewys as God se koninklike verteenwoordiger om die aarde te beheers. God het sekere magte en verantwoordelikhede aan die mens toevertrou soos besluite neem oor die mens self, sy medemens en die skepping. Heers beteken dus bestuur, met oorleg gebruik, bou, beskerm, bewaar en bekendstel. Omdat die bestuursfunksie aan die mens as mag en verantwoordelikheid toevertrou is, kan en moet die mens dus ook idees, emosies, denkpatrone en persepsies bestuur, maar dan so dat hy/sy in hulle toepassing die Skepper kan reflekteer. 
Deur die sondeval was daar 'n aantasting van die beeld van God, maar die beeld van God het nie verlore gegaan nie (vgl. Gen. 9:6; 1 Kor. 11:7 en Jak. 3:9). Die heerlikheid van die kindskap verdwyn egter (Mathews, 1996:164). Die feit dat die nuwe mens geskep moet word na die beeld van Christus, beteken dat daar 'n aantasting van die beeld van God was en die handhawing van die mens as mens na die sondeval moet net aan die genade van God toegeskryf word (vgl. Ef. 4:23, 24; Kol. 3:9b-10; 1 Kor. 15:49; vgl. Louw, 1999:205; Hiebert, 1991,181).

Die herskepping vind in Christus plaas (Ef. 2:10). Deur die genade van God is die nuwe mensheid geskep na die beeld van Christus en deur sy volmaakte gehoorsaamheid het Hy lewe en heerlikheid verwerf vir die gelowiges. Die nuwe mens is geskape "na/volgens God" (Ef. 4:23, 24), wat beteken volgens die beeld van God (Floor, 1995:169). Beeld van God in Efesiërs 4 is ontleen aan Genesis 1:26, 27 en dit beteken dat die nuwe mens God nou kan verbeeld in sy/haar gesindheid en in wat hy/sy sê of doen. Die ware beeld van God is Christus (2 Kor. 4:4) aan wie die mens gelykvormig moet word. Die verander word na die beeld van Christus is ' $n$ voortdurende proses met die vooruitsig om in die nuwe aioon volkome gelyk te wees aan die beeld van die verheerlikte Christus (vgl. 1 Kor. 15:49; Holleman, 1996:134). Botha (1993:772) lei uit 1 Korintiërs 15:49 af dat Paulus sy lesers oproep om in hierdie lewe reeds 'n bepaalde wesensgelykheid te openbaar met die werklike hemelse mens. In hulle geestelike bestaanswyse moet die lesers hulle lewe nou in ooreenstemming bring met die gedragswyse van Jesus wat as mens (die laaste Adam) kom leef het (Botha, 1993:773).

Die beeld (reklame) wat ons kragtens ons wese as kerk van Christus moet uitstraal (adverteer), is om rein te wees soos Jesus rein is (1 Joh. 3:3), in die lig lewe soos Hy in die lig is (1 Joh. 1:7), en regverdig sal leef soos Hy regverdig is (1 Joh. 3:7). Die gelowige reklameer dus tegelykertyd sy/haar Verlosser en hom/haarself. God maak dit vir die gelowige moontlik om hierdie beeld te reflekteer deur Christus en die kragtige werk van die Heilige Gees (König, 1994:40).

\subsection{Die Here se heerlikheid sien en weerspieël (2 Kor. 3:18)}

In 2 Korintiërs 3:18 dui Paulus aan hoe die kerk in staat gestel is om, as beeld van Christus, die heerlikheid van die Here te weerspieël. Die begrip "heerlikheid" kom agt keer in 2 Korintiërs 3:7-11 en drie keer in 3:18 voor. Dit toon die belang daarvan dat die heerlikheid van die Here gesien en weerkaats moet word. Die konteks waarin hierdie gedeelte voorkom (2 Kor. 2:14-6:10) gaan oor die integriteit van Paulus se bediening (Sloan, 1995:138). Dit gaan oor die interpretasie van Moses se geskiedenis, veral soos in Eksodus 34:33-35 verhaal word (Savage, 
1996:150). Moses se sluier is afgehaal toe hy in die teenwoordigheid van God gekom het, maar hy het die ongewone ervaring gehad dat hy sy gesig moes bedek om nie die heerlikheid van God aan die volk te weerkaats nie (vgl. Gleason, 1997:67-77). Die volk se hart was verhard en daarom was dit vir hulle onmoontlik om God se heerlikheid te sien en self te weerspieël (Hafemann, 1992:40).

Paulus stel in 2 Korintiërs 3:18 dat alle gelowiges nou met onbedekte gesig die magtige, regstreekse openbaring van God se heerlikheid kan verduur omdat hulle harte verander is (Garland, 1999:198). Soos die Here die sluier gelig het toe Moses in sy teenwoordigheid verskyn het, so lig die Heilige Gees die sluier vir gelowiges. Waar die Gees van die Here is, daar is die bedekking van letterknegtery en misverstand weggeneem sodat die gelowiges God in Christus in die lig van die evangelie kan sien (Du Rand, 1999:1531). Christus het met sy menswording die heerlikheid van die Vader hier op aarde kom weerkaats, want Hy het die Vaderbeeld geleef, gepreek en met sy opstanding kragtig geopenbaar. Gelowiges kan nou deur Christus, die Middelaar, tot God nader en sy heerlikheid met onbedekte gesig sien, omdat die heerlikheid van God nou van Christus uitstraal (vgl. 2 Kor. 4:4, 6; Kruse, 1991:98).

Die gelowiges is bevryde mense (die sluier is weggeneem) sodat hulle die heerlikheid van die Here kan raaksien en verstaan. En wanneer hulle die heerlikheid kan sien, verander die Heilige Gees hulle om ook die heerlikheid uit te straal. Die Heilige Gees stel die gelowige in staat om die heerlikheid van die Here te kan sien en die Gees vernuwe die gelowige se lewe sodat die beeld van Christus in die gelowige al meer sigbaar word en daarmee weerspieël word. Christus woon deur die Heilige Gees in die gelowige en verander die gelowige daagliks meer en meer om die heerlikheid van Christus te vertoon (Du Rand, 1999:1531). So deel die gelowige aan die heerlikheid van Christus en straal dus ook sy/haar eie heerlikheid uit.

\subsection{Samevatting}

God gee aan die mens die identiteit van beeld en verteenwoordiger van God. Omdat God die mens, en deur Christus veral die kerkmens, in 'n Vader-kind-verhouding plaas, kan die gelowige God se heerlikheid as sy beeld en verteenwoordiger in sy gesindheid en optrede reflekteer. Sy roeping om as beeld/verteenwoordiger te heers hou 'n bestuursfunksie in waardeur gelowiges ook persepsies kan en moet bestuur. Omdat die gelowige meer en meer na die beeld van Christus verander word, moet hy tegelyk sy Verlosser as die kerk self reklameer. Hiertoe word hy in staat gestel deur die Heilige Gees om in die Bybel die heerlikheid van 
God in Christus te sien en te verstaan - 'n proses waardeur hyself getransformeer word om die heerlikheid te kan weerspieël.

\section{Riglyne aan die kerk oor hoe sy haarself, haar oortuigings, haar waardes kan oordra}

Is daar sekere riglyne aan die kerk gegee oor hoe sy haarself en haar oortuigings en waardes moet oordra? Snitte uit drie Skrifgedeeltes word in hierdie deel ondersoek: Matteus 5:13-16, 1 Tessalonisense 1:8-10 en 2:1-12.

\subsection{Sout vir die aarde en lig vir die wêreld (Matt. 5:13-16)}

Terwyl Jesus in die Saligsprekinge die essensiële aard van die burgers van die nuwe Koninkryk beskryf, dui Hy met die metafore "sout" en "lig" die invloed aan wat hierdie burgers op die wêreld kan en behoort te hê (vgl. Porter, 1995:51-58). Terwyl verse 11, 12 die lesers opgewonde gemaak het oor die groot beloning wat in die hemel wag, konfronteer verse 13-16 die lesers met harde take wat hulle in hierdie wêreld moet volvoer. Maar is die armes van gees, die sagmoediges, treurendes, barmhartiges en vredemakers in staat om 'n blywende invloed in die wêreld uit te oefen? Kan hulle persepsies verander en ten goede bestuur?

Kerk en wêreld is twee onderskeie gemeenskappe wat tog verwant is aan mekaar. Die metafore sout en lig beskryf die aard van die gemeenskappe: die wêreld is 'n donker plek met geen lig van sy eie en daarom is 'n eksterne bron van lig nodig om die wêreld te verlig. 'n Ander eienskap van die wêreld is dat dit voortdurend besig is om te vergaan, om te verrot. Die wêreld kan homself nie keer om slegter te word nie en slegs sout wat van buite af gegee moet word, kan help bewaar. Daar is dus 'n fundamentele verskil tussen Christene en nie-Christene. "Julle", met klem vooropgestel, en julle alleen is sout en lig en moet dit vir die wêreld wees. Neem dus die verantwoordelikheid op wat hierdie verskil met die wêreld op julle plaas (Jones, 1995:360).

\section{- Sout vir die aarde}

Jesus gebruik twee huishoudelike metafore. Elke huisgesin, selfs die armstes, gebruik sout en lig, en sout en lig het één ding in gemeen: hulle gee hulleself. Soutkorrels is klein en skynbaar onbelangrik, maar die krag daarvan is groot solank as dit handel op die wyse waarop dit veronderstel en toegerus is om op te tree (Betz, 1995:160). Daar is verskillende betekenisse wat aan sout geheg word. Die mees algemene is dat dit bederf keer, maar sout is ook gebruik om geur te gee (Job 6:6) 
en as deel van die offers (Lev. 2:13; Eseg. 43:24: Harrington 1991:80). Daar is selfs 'n standpunt dat Jesus sy volgelinge "sout vir die aarde" verklaar het om hulle eerder as bemesting vir die aarde te kwalifiseer as mense wat bederf moet teëstaan (Kreider, 1989:36). Dié kenmerk van die sout is die genitief "van/vir die aarde", want die aarde is die plek waar die lesers lewe en vanwaar hulle op pad is na die nuwe lewe. Die lewe op aarde is die lewe van ekstreme: tussen armoede en rykdom (Matt. $5: 3)$, dood en lewe (5:4), sagmoedigheid en arrogansie (5:5), geregtigheid en diskriminasie (5:6), genadeloosheid en barmhartigheid (5:7), onreinheid en reinheid (5:8), oorlog en vrede (5:9) en vervolging en hemelse beloning (5:10-12). Daarom beteken sout vir die aarde dat gelowiges betrokke moet raak by die aarde en sy lewe, omdat hulle hulleself moet beskou as die mees belangrike bestanddeel van hierdie lewe (Betz, 1995:158).

Die voorwaarde is dat sout sy soutgehalte moet behou. Natriumchloried is ' $n$ baie stabiele chemiese samestelling wat nie sommer verander nie. Met sout wat "verslaan" of "laf geword het" kon die volgende beeld by die eerste lesers opgekom het: Sout is beskou as die wit poeier om die Dooie See wat ook natriumchloried bevat het, maar dit kon maklik weggewas word. Die oorblywende wit poeier is sout genoem, maar het nie gesmaak en geword soos sout nie. Dit was net stof waarop die mense getrap het (Stott, 1992:60; vgl. Louw \& Nida, 1988:52). Maar daar is ook 'n ander moontlike verklaring: daar is 'n regstreekse verbinding tussen die "laf wees" ( $\mu \omega \rho a \iota \nu \in \iota \nu)$ van die sout en die "dwase man" ( $\mu \omega \rho \hat{)})$ in Matteus 7:24-27. Die gelowiges is hiervolgens geroep om sout vir die aarde te wees, om die wysheid van God in die dwase wêreld te bring. Wanneer gelowiges nie meer die wysheid van God in die wêreld indra nie, het hulle die sin van hulle besondere plek verloor (Van Bruggen, 1990:90; Betz, 1995:157). Dit kan ook wees dat die sout wat verslaan in verband met Matteus 5:11 staan en dan beteken: As 'n gelowige nie die lyding wil aanvaar wat sy roeping in die wêreld meebring nie, dan verloor sout sy krag (Minear, 1997:36).

\section{- Lig vir die wêreld}

Met die verklaring van die armes van gees, ensovoorts, as die lig vir die wêreld neem Jesus 'n tradisionele Joodse aspirasie op, naamlik om die intellektuele leiers van die wêreld te wees. Dit is wat die Jode van Jesaja 42:6 gemaak het sodat hulle lig vir die nasies en oë vir die blindes kan wees (Betz, 1995:160). Jesus, en nie die Jode nie, is die Lig vir die wêreld (Joh. 8:12; 9:5) en die gelowiges is lig vir die wêreld deur Jesus se beeld uit te straal. Daarom is die lig vir die wêreld die navolging van Jesus, deur veral dit wat Hy in hierdie rede preek, te gehoorsaam. Die geseëndes is nie vanself lig nie: Jesus het deur sy gesaghebbende 
uitspraak die gelowiges so hoog geplaas (as stad op 'n berg en as 'n lamp op 'n stander). Die bouer van die stad wil dat hulle lig gesien word (bv. as baken) en die vrou wat 'n lamp op 'n stander sit, wil hê dat die lig oor alles in die (eenkamer-)huis uitstraal (vgl. Jes. 63:7-14; Jones, 1995: 363).

Deur die doen van goeie werke skyn die lig. Die kriptiese stelling in Matteus 5:14 is die toepassing van Psalm 43:3 waarmee die lig en waarheid verstaan moet word as die prediking van Jesus wat die gelowiges moet uitdra en as dit wat die wêreld benodig (Derrett, 1992:175). Lig in die Bybel is simbool van waarheid en die dra van getuienis (evangelisering) is om lig vir die wêreld te wees. Maar goeie werke mag nie tot glo en oordra van die waarheid beperk word nie, want dit sluit ook liefdesdade in, omdat liefdesdade lojaliteit teenoor God en die sorg vir die medemens uitdruk. Die lig van die geseëndes is die Gewer van die seëninge, Christus, se lig en hulle werke is sy werke wat in en deur hulle gedoen word. Die goeie werke sal die ontvangers bevoordeel omdat hulle getuies word en beweeg word om te doen wat elke gelowige as lig bevoorreg is om te doen: om God te verheerlik (Betz, 1995:164). Dit gaan dus nie primêr om die goeie werke as sodanig nie, maar om die getuienis wat hulle gee van die innerlike skat van Jesus se volgelinge, naamlik die Koninkryk en die versoende verhouding met God.

In Matteus 5:13-16 word die kerk opgeroep om sy unieke aard, wat uit genade aan hom gegee is, uit te straal. Die twee metafore sout en lig beklemtoon die betrokkenheid van die kerk by die openbare lewe. Die kerk wat buite die openbare lewe wil staan, is nie meer kerk nie. Dit beteken dat die kerk in hierdie proses 'n baie fyn balans moet handhaaf tussen konstruktiewe deelname en die handhawing van sy identiteit (Robinson, 1997:281). Om dit te doen moet die kerk die wêreld binnedring, moet dit verderf teëwerk deur veroordeling en protes, maar die vervalle mensheid benodig meer as hindernisse om hulle te stop om nog slegter te word. Die sout/kerk is nie daar vir homself nie, maar vir die kos/ wêreld. Die liefdesdade van gelowiges moet vir almal sigbaar wees, want egte liefde kan nie weggesteek word nie. En dit kan nie anders as om God te verheerlik nie, want God is liefde (Van Zyl, 1999:1124). Die koms van die Koninkryk beteken dat Christus gawes gee om die liefdesgebod deur goeie dade uit te leef (Pottner, 1997:121). Vanuit hierdie sfeer straal hulle die heerlikheid van God uit en wanneer ander dit sien en daardeur verander word, dan straal hulle ook die heerlikheid van God al wyer uit. 


\subsection{Die gemeente as uitsaaistasie (1 Tess. 1:7-10)}

\section{- 'n Voorbeeld en 'n klankbord}

Paulus kon slegs 'n maand of twee in Tessalonika werk voordat hy daaruit moes vlug. Hy kon dus nie sy prediking tot sy eie bevrediging mondeling voltooi nie en moes gevolglik per brief "aanvul wat nog aan hulle geloof ontbreek". In dié brief dank hy God vir sy genadige uitverkiesing van die gemeente wat bewys word deur die krag waarmee die evangelie Tessalonika getref het, asook deur die werk van die Heilige Gees, waardeur die gemeente die evangelie met die blydskap wat van die Heilige Gees kom, aangeneem het (1 Tess. 1:3-6). Die gevolg van die ontvangs van die evangelie was verrassend. Die gemeente het volgelinge van die Here geword. Hulle het deur die prediking en die voorbeeld van die predikers die Here leer ken. Met die aanvaarding van die evangelie van verlossing in Christus, kom ook die verdrukking $(\theta \lambda \iota \psi \hat{i})$, 'n woord wat dui op druk van ernstige aard (vgl. Hand. 17:5-9). Die gemeente raak dus dadelik betrokke by die wêreld waarin hulle lewe en onttrek hulle nie daarvan nie, ten spyte van die verdrukking wat dit meebring. So word die volgelinge van die Here in Tessalonika self voorbeeld (TUTÔ̂), en hulle lewenshouding en lewenstyl 'n model vir almal om hulle. Die evangelie wat op die gemeente gerig was, het in hulle persoonlike lewe en in die lewe van mense oor 'n baie wye gebied 'n geweldige uitwerking gehad.

Die evangelie het gekom, regstreeks op hulle gerig en het van hulle af weerklink. Paulus plaas "van julle af" met klem voorop, want die gemeente is die sentrum vanwaar die Woord versprei word (Ware, 1992:128). Die beeldspraak wat hier gebruik word, dui op 'n harde klank wat oor 'n wye gebied gehoor is (Louw \& Nida, 1988:413) en die perfektum $(\epsilon \xi \eta \chi \eta$ Tal) toon dat die voortbring of die weerklank van die oorspronklike klank 'n uitwerking het, want die klank vul nog steeds die lug (Martin, 1995:63). Die gemeente het inderdaad 'n klankbord van die evangelie geword, want die blye boodskap is met blywende resultaat voortge-eggo, nie net in Masedonië en Agaje nie, maar oral. Mense het oral daarvan gepraat sodat Paulus-hulle nie nodig gehad het om iets meer daaroor te sê nie (vgl. 1 Tess. 4:9 en 5:1). Die ligging van Tessalonika het die weerklank bevorder, want dit was op die hoofweg tussen die Ooste en die Weste geleë (De Klerk, 1983:352).

\section{- Die boodskap}

Die gemeente wat die Woord met blydskap ontvang het, kon dit nie krampagtig vir hulleself hou nie, want die verspreiding van die evangelie was die resultaat van 'n dinamiese Christelike lewe. Wat was die 
boodskap, die persepsie, wat weerklink het oral waar Paulus gekom het? Die inhoud van die verhaal wat oor daardie gemeente vertel is, word in 1 Tessalonisense 1:9 en 10 vertel: hulle gasvryheid in die ontvangs van sendelinge, hulle radikale wegdraai van afgode en hulle draai na God, hulle blymoedige dien van die Here en hulle sterk verwagting van Christus se wederkoms (Martin, 1995:64).

Paulus het verskeie kere berigte ontvang van die gasvrye ontvangs van predikers, wat 'n bewys was van die gemeente se liefde vir die Inhoud van die prediking, Christus. Die verwondering oor die bekering van die gemeente het wye bespreking ontlok: die bekering het 'n negatiewe en positiewe aspek: Die omkeer is 'n finale wegdraai van die afgode en die draai van hulle gesig, hulle hele lewe, na God. Positief bring "hulle draai na God" hulle in 'n intieme, van-aangesig-tot-aangesig-verhouding met die ware God. Want bekering beteken nie net om iets prys te gee nie, maar veral om lemand te ontvang. Die mens wat tot die lewende en waaragtige God bekeer is, tree uit diens van die afgode en tree toe tot die diens van die ware God. Om te dien is om met alles wat jy is en het tot God se beskikking te wees. Die praesens infinitief $(\delta o v \lambda \epsilon \cup \in \iota \nu)$ wys dat dit 'n lewe van voortdurende, volledige en volmondige diens aan God is. Hierdie diens word deur die liefde alleen gemotiveer en geïnspireer (De Klerk, 1983:354).

$\mathrm{Na}$ die bekering is daar 'n "reeds" (diens aan God) en 'n "nog nie" (Christus kom). En daarom gaan diens aan God hand aan hand met verwagting. Die verwagting sluit tegelyk 'n vooruitgryp na dit wat sal kom en impliseer ' $n$ aksie in die hede, naamlik die heiliging van hulle hart en lewe. Die opstanding van Christus is die bewysgrond en waarborg van sy wederkoms, want sy verlossingswerk met sy eerste koms, wat met sy opstanding op 'n oorwinning uitgeloop het, vorm die basis vir sy werk as Verlosser by die wederkoms. Die gemeente was dus sowel model (1 Tess. 1:7) as boodskapper (1 Tess. 1:8) van die evangelie en het met woord en lewe die evangelie versprei.

\subsection{Hoe skuld deur assosiasie beantwoord kan word (1 Tess. 2:1-12)}

Rondtrekkende propagandiste van die heidense godsdienste en sogenaamde wonderdoeners het hulle skuldig gemaak aan vleitaal teenoor mense, aan gierigheid om net geld te maak uit hulle optredes en aan eersug om die eer van mense te soek. Nou word Paulus en sy medewerkers geassosieer met hierdie mense en van dieselfde dinge beskuldig. Dit is skuld deur assosiasie (vgl. Winter, 1993:55-74). 
Hoe beantwoord Paulus hierdie, amper moderne, tegnieke van sy teenstanders? In omgekeerde orde doen hy dit met drie metafore wat riglyne vir die hantering van valse persepsies bied. Teenoor die beskuldiging dat Paulus-hulle die eer van mense soek, stel hulle dat hulle soos babatjies sonder bybedoelings, pretensieloos en deursigtig opgetree het (Janse van Rensburg, 1999a:1512; vgl. Fowl, 1990:469473). Teenoor die beskuldiging dat hulle net wil geld maak, stel Paulus dat hulle uit liefde, soos dié van 'n ma wat kos en haarself gee, hulle lewe en hulle hart tot beskikking van die gemeente gestel het. En teenoor die beskuldiging van vleitaal, stel Paulus dat hulle soos 'n pa die gemeente ferm in liefde vermaan en aangemoedig het.

\subsection{Samevatting}

Hoe moet die kerk haarself, haar oortuigings en waardes oordra? Die kerk moet die aard, wat aan haar gegee is, uitdra deur konstruktief in die wêreld betrokke te wees terwyl sy haar eie identiteit handhaaf. Dit moet sy doen deur protes waar nodig, deur met wysheid smaak aan standpunte en lewenswyses te gee, deur die lig van die waarheid in alle aangeleenthede uit te dra en dit met liefdesdade te bevestig. Hierin behoort die kerk die gesindheid uit te straal van blydskap in alle omstandighede. Deur voorbeeld te wees en die weerklank van die evangelie te wees het die kerk die potensiaal ontvang om die Blye Boodskap wyd uit te dra. Dit kan gedoen word deur gasvryheid, 'n sigbare intieme verhouding met God en openlike diens aan God voor die oë van ander, asook deur 'n sterk wederkomsverwagting. Verkeerde persepsies (soos skuld deur assosiasie) kan verander word deur tegelyk deursigtig en pretensieloos (soos babas) op te tree, en in liefde jouself te gee (soos 'n ma) en ferm in liefde te vermaan en aan te spoor (soos 'n pa).

\section{God leer ons om persepsies te bestuur}

Die persepsies wat ander mense oor die volk van God het, beïnvloed ook hulle persepsies oor God. God bestuur, selfs sonder dat die gelowiges altyd daarvan bewus is, hierdie persepsies en tegelyk gee Hy aan sy volgelinge riglyne oor hoe hulle persepsies moet teëwerk, positief moet beïnvloed en verder moet bestuur. Dit raak die soort van reklame wat in hierdie verband behoort gedoen te word. Twee snitte uit Esegiël 36 en uit 1 Petrus 2 en 3 word gemaak in 'n poging om tot veralgemenings hieroor te kom. 


\subsection{God se volk is God se reklame onder die volke (Eseg. 36:16-38)}

Toe die Here in Deuteronomium 7 aan die trekkende volk Israel hulle oorsprong en bestemming verduidelik, staan dit in verband met die nasies met wie hulle in aanraking kom. Enersyds moet hulle die nasies met hulle afgode uitroei en andersyds 'n banier vir die volke wees. Die uitroei het daarmee te doen dat die land waar die heilige God sy volk laat woon, heilig moet wees, dus gestroop van alle afgode. Die ander volke moes uit die krag, wyse van lewe en toewyding aan die Here 'n persepsie vorm, nie net van Israel nie, maar ook en veral van die God van Israel.

Esegiël werk onder die volk wat in ballingskap is en in Esegiël 33-48 gaan dit oor die heropbou van Israel. Die motief van God se ingryping in die ballingskap is die sorg vir die eer van sy Naam (Esegiël 36:16-38). Dit gaan in hierdie verse om die krisis oor die Here se eer (verse 17-21), die herstel van God se eer (verse 22-32), en die herwinning van God se eer (verse 33-38), eers onder die nasies en dan in Israel (Block, 1998:343). Esegiël vertel van die verkeerde persepsie wat die volk Israel van God het, asook die valse persepsie wat die ander volkere van God het, en dan veral hoe God hierdie persepsies verander ter wille van die heiliging van sy Naam. Voor die ballingskap na Babel was daar onder die volk gruwelike afgodery, prostitusie en selfs kinderoffers, wat toon dat die volk die persepsie gehad het dat God naas of selfs ondergeskik aan die ander volke se gode gestel kan word. Die land is sowel deur godsdienstige as sosiale oortredings verontreinig (Biggs, 1996:115), so erg dat dit ander besmet het wat met hulle in aanraking gekom het (Block, 1998:345). Hulle kon nie langer in God se land woon nie en moes 'n plek kry onder die onreines. Agter die wegjaag uit hulle land lê die verbondsvloek sodat die land sy "sabbatical rest" kan kry (Block, 1998:347; vgl. Lev. 26:33-45 en 2 Kron. 36:21).

Waar die volk egter nou kom, ook in die onrein Babel, ontheilig hulle God se Naam. Want vir die volke was dit destyds so: 'n sterk volk het 'n sterk god en 'n swak volk 'n swak god. Die persepsie het dus bestaan dat Jerusalem se ondergang en die verwoesting van die tempel 'n neerlaag vir die Here was, gemeet aan die maatstawwe waarmee volkere die gode meet. Die vreemdelinge spot met die feit dat die volk van die Here geskei is van die land van die Here (Klein, 1988:146). Die persepsie was dat God nie in staat was om sy volk in sy land te hou nie en dat Hy nie die wegvoering kon keer nie (en dit terwyl Hy hulle weggestuur het!). Maar God is anders as die afgode wat uit die volk voortkom en saam met die volk ondergaan. Hy was vóór Israel daar en bestaan sónder Israel en sal ná Israel nog daar wees. Israel het Hom nie gemaak nie, maar Hy vir 
Israel. Daarom openbaar God nou sy mag om sodoende die valse persepsie oor sy eer reg te stel. Hy sal sy volk herstel deur hulle innerlikgeestelik nuut te maak en hulle terug te bring na hulle land. Hulle sal nie net skoongewas word deur die vergiffenis van sonde nie, maar daar sal 'n radikale breuk wees met die sondige verlede voor die ballingskap. Die Gees wat hulle sal ontvang, sal hulle God se heiligheid met nuwe oë laat sien (Cooper, 1994:315). Juis deur die terugkeer uit die ballingskap word die verkeerde persepsie by die volke reggestel.

Die openbaringsgeskiedenis verhaal Israel se verdere ontrouheid na die herstel van die ballingskap. Dan gryp God in ter wille van sy Naam en skep onder die nuwe Hoof, Christus, sy nuwe volk uit al die nasies. So kom die nasies daartoe om God te verheerlik en sal hulle instrumente wees om Israel ook tot aanbidding van die ware God te bring. Ter wille van die regstel van valse persepsies van God en sy nuwe volk doen God magtige dade, want God se volk is ook sy reklame onder die nasies van die wêreld.

\subsection{God gee sy kerk verantwoordelikhede om persepsies te bestuur (1 Pet. 2:11, 12, 15; 3:15)}

Die gelowiges moet nie net rekening hou met die feit dat God in sy almag persepsies kan teëgaan, verander en bestuur nie, maar moet ook raaksien dat God aan sy kinders verantwoordelikhede gee om dit in sy diens te kan doen. 1 Petrus is hiervan 'n voorbeeld.

\section{- Verander persepsies deur goeie gedrag (1 Pet. 2:11, 12,15)}

Die eerste lesers van hierdie brief het gely onder openlike diskriminasie teen hulle, want hulle het geen eiendom, burgerskap en die voorregte daaraan verbonde gehad nie. Hulle is beswadder deur die bevolking en die owerhede. Hoe moet gelowiges lewe onder die kritiese oog van die medemens wat daarop uit is om kwaad van hulle te praat en sodoende 'n absoluut negatiewe persepsie oor hulle te skep?

Die gelowiges is vreemdelinge en bywoners in die wêreld, nie net omdat hulle geen regte in die samelewing gehad het nie, maar veral omdat God se uitverkiesende liefde hulle anders (vreemd vir ongelowiges) gemaak het (Van Houwelingen, 1991:88). Gelowiges is die nuwe volk van God wat dit bewys deur lewens te lei wat God se heiligheid reflekteer. Hulle moet dus opregte liefde vir mekaar hê, saam God dien en sy magtige werke verkondig. In hierdie dinge het Petrus veral in 1 Petrus 1:3-2:10 op die gelowiges self gefokus, naamlik op hulle verhouding met God, met mekaar en op hulle geestelike groei en ontwikkeling. Nou fokus hy op hulle plek en rol in die wêreld (Marshall, 1991:77). In 2:11-12 word die 
basiese opdrag in verband met vreemdelingskap in die wêreld gegee en in die volgende verse word verskeie toepassings van hierdie algemene opdrag gemaak.

Een van die sleutelwoorde oor die vereistes van hulle optrede in die wêreld is "onthouding" (nie toegee aan), wat gesien word as uitdrukking van wysheid, van die lewenskuns om verstandig met jouself om te gaan en kontrole te hê oor jou begeertes, veral die menslike begeerte om kwaad met kwaad te vergeld. Die reaksie (persepsie) hierop by die niegelowiges sal aggressie wees en gevolglike kwaadpraat van gelowiges (Giesen, 1998:150). Onthouding van die begeerte om te vergeld is die primêre opdrag, maar die positiewe vloei daaruit voort: hou aan goed doen ondanks enige verontregting. Die ongelowiges moet die voorbeeldige lewe van Christene sien. Vir "sien" gebruik Petrus 'n werkwoord $(\epsilon \pi$ $\pi \tau \in \mathcal{V} \omega)$ wat beteken "insien, deursien". Die insig breek deur, want die goeie werke slaan 'n bres in die onbegrip en laat mense meteens insien waarom Christene hulle juis so gedra: God is naamlik hier aan die werk. Goeie werke is so deursigtig dat hulle die lig van God deurlaat (transparant) en die Christene se verbinding aan Christus onthul. Hulle sien in dat hierdie soort lewenspatroon en gesindheid voortkom uit hulle verhouding met Christus en dit slaan kritiek om in bewondering, sodat God verheerlik word (Van Houwelingen, 1991:90). Juis deur hierdie werkwoord te gebruik, toon Petrus hoe persepsies verander en bestuur kan word. Deur hulle houding moet hulle ander so aan die dink sit dat met die insig ook geloof deurbreek, want God se eer is op die spel. Petrus sien die gewysigde houding in eskatologiese perspektief, want dieselfde mense wat hulle nou smalend uitlaat oor Christene sal God by die eindoordeel verheerlik.

Hoe maak Christene 'n einde aan mense se slegpraat? In 1 Petrus 2:15 gee Petrus die antwoord. Deur die goeie te bly doen is dit moontlik om die skindertonge tot stilswye te bring. Petrus merk in die kritiek van owerhede en onderdane sowel onkunde as onverstandigheid op, want hulle wil niks weet nie en wil niks begryp nie. Hulle probeer nie die feite kontroleer nie, glo maklik wat ander oorvertel, want almal hou van skandale. Daarom is groot inspanning nodig om hulle te weerlê deur die doen van goeie dade. Al sou mense deur die voorbeeldige lewe van Christene miskien nie dadelik positief verander nie, sou hulle swye tog boekdele spreek. 'n Riglyn om die kwaad te weerlê, word in 1 Petrus 2:16b en 17 gegee: dien God, respekteer alle mense, wees lief vir medegelowiges, vrees God en eer die keiser.

Net so ernstig as die vrees vir afbrekende aanvalle met die tong, is die vrees by Christene om altyd 'n koue skouer te kry, geïgnoreer te word en om so 'n gesiglose te word. Daarom kan dit wat vir Christene gesê word 
wat aktief met woorde oor hulle geloof aangeval word, ook van toepassing gemaak word op dié wie se geloof en hoop geïgnoreer en in stilte verdra word. Almal moet positief gebruik maak van die geleenthede wat hierdie vyandige situasies meebring.

\section{- Wees gereed om rekenskap te gee (1 Pet. 3:15)}

Roep die doen van die goeie nie outomaties die slegte op nie? Dit is bepaald wat die eerste lesers in die vyandige omgewing deur die veronregting ervaar. Die vertrekpunt vir hulle reaksie teenoor hierdie veronregting moet wees om aan te hou goed doen, want daarmee wys Christene dat Christus die Baas van hulle lewe is (Janse van Rensburg, 1999b:1725). 'n Goeie lewenswandel moet altyd veranker wees in 'n goeie gewete wat die vrymoedigheid gee om verantwoording teenoor ander te doen. Wie aanhou goeddoen ten spyte van onverdiende lyding, sal een of ander tyd gevra word hoe hulle dit regkry. Die gelowiges moet gereed wees om te antwoord wanneer hulle gevra word na die rede waarom hulle anders dink, praat en doen. Oral waar die nuwe lewe hom openbaar, sal daar kritiese vrae kom wat geleentheid vir geloofsgetuienis

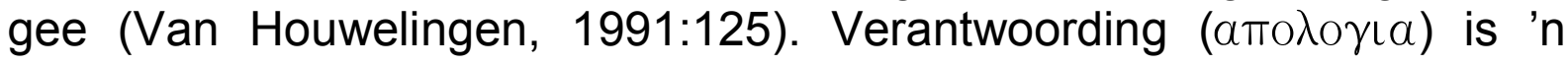
algemene antwoord op enige aandrang op die verduideliking van die hoop wat die gelowiges in hulle het (Perkins, 1995:62).

Meestal draai die vrae om die lewensgeheim van die gemeente, wat tegelyk vir die nie-gelowiges 'n geheim is: die hoop wat onder die gelowiges bestaan. Waar die wêreld sonder hoop en sonder God is (Ef. 2:2, 12), laat die Christelike hoop gelowiges lewe in die vaste vertroue op God, van Wie in die toekoms nog baie meer verwag word: die erfenis wat $\mathrm{Hy}$ beloof het en die genade wat gelowiges by die wederkoms van Jesus Christus sal ontvang. Hierdie verantwoording moet gepaard gaan met "beskeidenheid (sagmoedigheid) en eerbied" wat kenmerkend is van die innige verbondenheid aan God. Die beskeidenheid teenoor antagonistiese mense is in ooreenstemming met die gelowiges se algemene gedragspatroon, wat 'n goeie gewete behou wat hulle nie veroordeel nie (Marshall, 1991:116). Die beskeidenheid toon dat dit God se krag is wat in die gelowiges se optrede sigbaar word en dit kan ander help om tot Christus te kom. 'n Skerp antwoord kan egter lei tot verdere verharding.

Die hoop waarvan die gelowiges 'n verduideliking in die gees van beskeidenheid teenoor mense en eerbied teenoor God moet gee, kan die gemeente se passie genoem word. Passie is die gemeente se onverdeelde en onafgebroke toewyding aan die Here en aan mekaar, die kerk (vgl. 1 Kor. 7:35 en 1 Tim. 4:7). Wanneer Paulus sy verhouding met die Korintiërs na groot hartseer herstel het, wys hy op die passie wat dit by 
die gemeente gebring het. Hulle het ernstige ywer, nie net om verantwoording te doen teenoor wie dit van hulle eis nie, maar 'n passie vir die kerk in Korinte (vgl. 2 Kor. 7:8-13). Die passie vir die kerk, al gaan dit met hartseer gepaard, word die duidelikste vertolk as Paulus vir die gemeente in Korinte sê: "Ek waak oor julle met 'n ywer wat van God kom, want julle is soos 'n jongmeisie wat ek aan een man toegesê het as sy bruid wat ek vlekkeloos na hom toe wil bring. Die man is Christus!" (2 Kor. 11:2).

\subsection{Samevatting}

God leer die kerk hoe om persepsies te bestuur, want in die persepsie oor God en sy kerk gaan dit ten diepste om sy eer. Daarom bestuur Hyself persepsies oor sy volk deur verlossing, innerlike vernuwing en die bestuur van die geskiedenis. Tog gee Hy ook verantwoordelikhede aan sy kerk deur van hulle ' $n$ innerlike ingesteldheid te vra om nie aan die begeerte toe te gee om kwaad met kwaad te vergeld nie. Verder deur voortdurende deursigtige goeie dade te doen in die dien van God, die respekteer van alle mense, die liefhê van medegelowiges en die eer van die owerheid. Die kerk moet gereed wees wanneer sy gevra word na haar standpunte, lewenshouding en lewenstyl, veral as dit gaan oor die Christelike hoop, die sekerheid oor die toekoms en 'n lewe gekenmerk deur toekomsverwagting. Uit hierdie hoop straal die kerk se passie, se ywer vir Christus en sy bruid, wat noodsaaklik is om persepsies te kan bestuur.

\section{Gevolgtrekkings}

- Die kerk het 'n bepaalde identiteit, naamlik die beeld/verteenwoordiger van God, vernuwe na die beeld van Christus en uitstraler van die beeld van die Drie-enige God. Hierdie wesenseienskappe van die kerk stel hom in staat om God se advertensie in hierdie wêreld te wees en gee aan die kerk die roeping om met nuwe ywer die persepsies oor God, die kerk self en sy leefomgewing te bestuur.

- Om die aard, waardes en oortuigings van die kerk oor te dra, moet die kerk konstruktief by die wêreld betrokke wees, anders is die kerk nie sout en lig en weerklank van die evangelie nie. God gebruik in die reklame die verkondiging van sy Woord, ook die bruid van Christus. Sy dra ten diepste die beeld van die Bruidegom uit, maar in hierdie proses dra sy ook haar eie beeld as bruid uit. Omdat sy gerig is op die Bruidegom moet sy met haar gesindheid, optrede en woorde van haarself vertel. 
- God bestuur die persepsies oor Homself en sy volk en gee hierin ook verantwoordelikhede aan die kerk. God gebruik die reklame van sy kerk om in die wêreld persepsies oor Homself te vorm en te bestuur. Die kerk moet persepsies oor God en sy volk bestuur deur goeie werke te doen en rekenskap van haar hoop te gee. Die kerk kan dit net doen as daar by haar ' $n$ innerlike gesindheid van passie vir God en haar Bruidegom, Christus, is, maar ook 'n vurige passie teenoor haarself.

\section{Bibliografie}

BETZ, H.D. 1995. The sermon on the mount. A commentary on the sermon on the mount, including the sermon on the plain (Matthew 5:3-7:27 and Luke 6:20-49). Hermeneia - a critical and historical commentary on the Bible. Minneapolis : Fortress Press.

BIGGS, C.R. 1996. The book of Ezekiel. Epworth Commentaries. London : Epworth Press.

BLOCK, D.I. 1998. The book of Ezekiel. Chapters 25-48. The New International Commentary on the Old Testament. Grand Rapids : Eerdmans.

BOTHA, S.P. 1993. 1 Korintiërs 15:49b. 'n Hortatief of futurumlesing? Hervormde Teologiese Studies, 49(4):760-774.

COOPER, L.E. 1994. Ezekiel. The New American Commentary. Nashville : Broadman \& Holman.

DE KLERK, B.J. 1983. Die gesag van die prediking van die Nuwe-Testamentiese Briewe. Potchefstroom : PU vir CHO. (Th.D.-proefskrif.)

DERRETT, J.D.M. 1992. The light and the city: Mt. 5:14. The Expository Times, 103(6):174-175.

DU RAND, J.A. 1999. 2 Korintiërs. (In Die Bybellennium. Eenvolumekommentaar. Die Bybel uitgelê vir eietydse toepassing. Vereeniging : Christelike Uitgewersmaatskappy. p. 1526-1546.)

FLOOR, L. 1995. Efesiërs. Eén in Christus. Commentaar op het NieuweTestament. Kampen : Kok.

FOWL, S. 1990. A metaphor in distress. A reading of nepioi in 1 Tessalonians 2:7. New Testament Studies, 36(3):469-473.

GARLAND, D.E. 1999. 2 Corinthians. The New American Commentary. Nashville : Broadman \& Holman Publishers.

GIESEN, H. 1998. Lebenszeugnis in der Fremde. Zum Verhalten der Christen in der paganen Gesellschaft (1 Petr. 2:11-17). Studien zum Neuen Testament und seiner Umwelt, 23:113-152.

GLEASON, R.C. 1997. Paul's covenantal contrast in 2 Corinthians 3:1-11. Bibliotheca Sacra, 154(613):61-79.

GREENHALGH, S. 1992. Creative partnership in Genesis. Scripture Bulletin, 22:914.

HAFEMANN, S.J. 1992. The glory and veil of Moses in 2 Cor. 3:7-14: An example of Paul's contextual exegesis of the OT - a proposal. Horizons in Biblical Theology, 14(1):31-49.

HAMILTON, V.P. 1991. The book of Genesis. Chapters 1-17. The New International Commentary on the Old Testament. Grand Rapids : Eerdmans.

HARRINGTON, D.J. 1991. The gospel of Matthew. Sacra pagina series. Minnesota : Liturgical Press. 
HIEBERT, D.E. 1991. Romans 8:28-29 and the assurance of the believer. Bibliotheca Sacra, 148(590):170-183.

HOLLEMAN, J. 1996. Resurrection and Parousia. A traditio-historical study of Paul's eschatology in 1 Corinthians 15. Leiden : Brill.

JANSE VAN RENSBURG, J.J. 1999a. 1 Tessalonisense. (In Die Bybellennium. Eenvolumekommentaar. Die Bybel uitgelê vir eietydse toepassing. Vereeniging : Christelike Uitgewersmaatskappy. p. 1492-1525.)

JANSE VAN RENSBURG, J.J. 1999b. 1 Petrus. (In Die Bybellennium. Eenvolumekommentaar. Die Bybel uitgelê vir eietydse toepassing. Vereeniging : Christelike Uitgewersmaatskappy. p. 1713-1730.)

JONES, I.H. 1995. The Mattean parables. A literary and historical commentary. Supplements to Novum Testamentum. Leiden : Brill.

KLEIN, R.W. 1988. Ezekiel. The prophet and his message. Studies on personalities of the Old Testament. Columbia, South Carolina : University of South Carolina Press.

KÖNIG, A. 1994. Covenant partner and image: deriving anthropology from the doctrine of God. Journal of Theology for Southern Africa, 88:34-41.

KREIDER, A. 1989. Salty discipleship: Bringing new worlds of life. The Other Side, 25(2):34-37.

KRUSE, C.G. 1991. The second epistle of Paul to the Corinthians. The Tyndale New Testament commentaries. Grand Rapids : Eerdmans.

LENCHAK, T. 1996. Puzzling passages: Genesis 1:26. The Bible Today, 34:167.

LOUW, D.J. 1999. Pastoraat as vertolking en ontmoeting. Teologiese ontwerp vir 'n basisteorie, antropologie, metode en terapie. Nuwe hersiene uitgawe. Kaapstad : Lux Verbi.

LOUW, J.P. \& NIDA, E.A. 1988. Greek-English lexicon of the New Testament based on semantic domains. Goodwood, Cape : United Bible Societies.

MARSHALL, I.H. 1991. 1 Peter. The IVP New Testament commentary series. Leicester : InterVarsity Press.

MARTIN, D.M. 1995. 1, 2 Thessalonians. The New American Commentary. Nashville : Broadman \& Holman.

MATHEWS, K.A. 1996. Genesis 1-11:26. The New American Commentary. Nashville : Broadman \& Holman.

McGRATH, W. 2000. Christians are meant to advertise. Natal Witness: 21, June 14.

MINEAR, P.S. 1997. The salt of the earth. Interpretation, 51(1):31-41.

PERKINS, P. 1995. First and second Peter, James and Jude. Interpretation. A Bible commentary for teaching and preaching. Louisville : John Knox.

PORTER, L.B. 1995. Salt of the earth. Homiletic and Pastoral Review, 10:51-58.

POTTNER, M. 1997. Metaphern der universalen Liebe (Mt 5, 13a, 14a). Theologische Literaturzeitung, 122(2):105-122.

ROBINSON, P. 1997. The church in the public sphere. Some perspectives from Matthew 5:13-16. Missionalia, 25(3):274-284.

SAVAGE, T.B. 1996. Power through weakness. Paul's understanding of the Christian ministry in 2 Corinthians. Society for New Testament studies. Monograph series. Cambridge : University Press.

SLOAN, R.B. 1995. 2 Corinthians 2:14-4:6 and the new covenant hermeneutics - a response to Richard Hays. Bulletin for Biblical Research, 5:129-154.

SPYKMAN. G.J. 1992. Reformational theology: a new paradigm for doing dogmatics. Grand Rapids : Eerdmans.

STOTT, J.R.W. 1992. The message of the sermon on the mount. Christian counterculture. The Bible speaks today. Leicester : Inter-varsity Press. 
VAN BRUGGEN, J. 1990. Matteus. Het evangelie voor Israel. Commentaar op het Nieuwe Testament. Kampen : Kok.

VAN HOUWELINGEN, P.H.R. 1991. 1 Petrus. Rondzendbrief uit Babylon. Commentaar op het Nieuwe Testament. Kampen : Kok.

VAN LEEUWEN, R.C. 1997. Form, image. New international dictionary of Old Testament theology and exegesis. 5 volumes. Grand Rapids : Zondervan. 4: 643-648.)

VAN ROOY, H.F. 1996. Die sogenaamde Bybelse kultuurmandaat (Gen. 1:28 en 2:15) en ontwikkeling. 'n Ou-Testamentiese perspektief. Koers, 61(4):425-440.

VAN WYK, J.H. 1992. Imago dei: diskussie met Adrio König. In die Skriflig, 26(1):114.

VAN ZYL, H.C. 1999. Matteus. (In Die Bybellennium. Eenvolumekommentaar. Die Bybel uitgelê vir eietydse toepassing. Vereeniging : Christelike Uitgewersmaatskappy. p. 1111-1187.)

VERHOEF, G.C. 2000. Die noodsaak van 'n Bybelse mensbeskouing in berading: enkele snitte uit die Skrif en die praktiese implikasies daarvan. Potchefstroom : $\mathrm{PU}$ vir CHO. (M.A.-verhandeling.)

WARE, J. 1992. The Thessalonians as a missionary congregation: 1 Thessalonians 1:5-8. Zeitschrift fur die Neutestamentliche Wissenschaft, 83(1-2):126-131.

WINTER, B.W. 1993. The entries and ethics of orators and Paul (1 Thessalonians 2:1-12). Tyndale Bulletin, 44(1):55-74.

\section{Kernbegrippe:}

metafore vir die invloed van gelowig-wees

persepsies oor die kerk

sout/lig: metafore; betekenis

lig/sout: metafore; betekenis

\section{Key concepts:}

metaphors indicating the influence of believers

perceptions on the church

salt/light: metaphors; meaning

light/salt: metaphors; meaning 